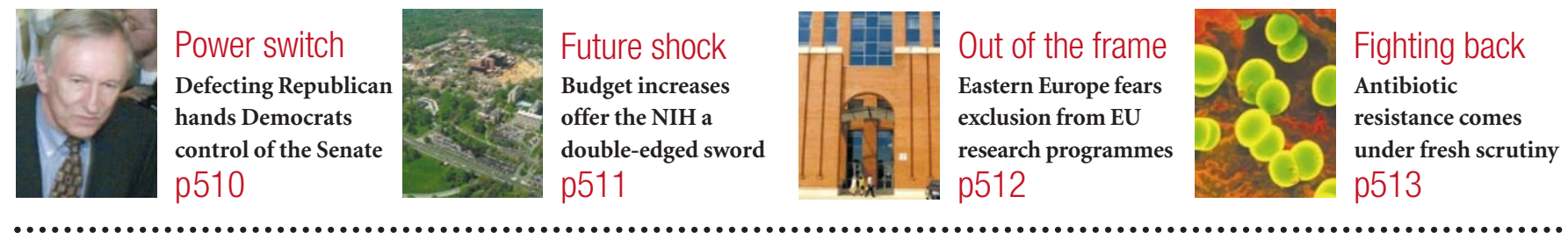

\title{
Data protection law threatens to derail UK epidemiology studies
}

\section{David Adam, London}

Epidemiological studies in Britain are being crippled by the overzealous application of legislation designed to protect personal data, claim leading researchers in the field. The epidemiologists warn that dozens of studies are under threat because doctors fear prosecution if they hand over information about their patients.

Britain is a world leader in epidemiology. But the 1998 Data Protection Act — which forbids personal data collected for one reason being used for anything else without informed consent - is threatening that position. "It's blocking everything from followup studies of people who received medical treatment 20 years ago to finding out what industrial hazards may be causing cancer," says Julian Peto, head of epidemiology at the Institute of Cancer Research near London.

Richard Doll of the Clinical Trial Service Unit at the University of Oxford, who in the 1950s established the link between smoking and lung cancer, calls the situation "potentially disastrous", and adds that much of his research would never have been done in the present climate.
Peto says that his study of asbestos-related cancer, funded by the government through the Health and Safety Executive, is being obstructed because the Department of Health now refuses to tell him which doctors have eligible patients. "It's ridiculous," he says. "Talk about the left hand not knowing what the right hand is doing."

Epidemiologists say matters have come to a head since September last year, when the General Medical Council (GMC), which regulates the medical profession, issued guidelines warning doctors that they risked prosecution if they passed on data without explicit consent. Until then, most doctors had assumed that supplying data to researchers was exempted by a 'public interest' clause in the law. "The GMC's guidance has left the medical research community in turmoil," says Michel Coleman, head of the cancer and public-health unit at the London School of Hygiene and Tropical Medicine. He wants the GMC to withdraw or modify its guidelines.

A spokesman for the GMC insists that it had no choice but to issue the guidelines in their present form. "After taking legal advice it became clear to us that doctors were acting

\section{Arson hampers conservation work}

\section{Rex Dalton, San Diego}

A plant research facility at the University of Washington was severely damaged by fire last week, in what appears to be one in a series of destructive attacks by militant environmental activists.

The university's Center for Urban Horticulture in Seattle, where ecologists, botanists and molecular biologists study biodiversity and plant genetics, suffered damage estimated at $\$ 3$ million in the incident on 21 May. Vehicles and buildings at a tree plantation in Clatskanie, Oregon, which works with researchers at the centre, were also damaged in a simultaneous attack.

The Federal Bureau of Investigation is investigating the fires, which an anonymous call claimed was the work of the Earth
Liberation Front (ELF). The letters 'ELF' were also daubed in graffiti at the Oregon plantation. The ELF has been linked to a series of attacks on industry, tourist and logging facilities in the Pacific Northwest.

The main target for the attack appears to be Toby Bradshaw, who heads a project studying genetically modified poplar trees. Bradshaw says that his research materials and data were backed up elsewhere.

But the work of other scientists, such as Sarah Reichard, who studies the restoration of endangered forest plants, has suffered.

"These people are really ignorant, attacking scientists who spend their lives protecting the environment," says Reichard, who is secretary of the Society for Conservation Biology.

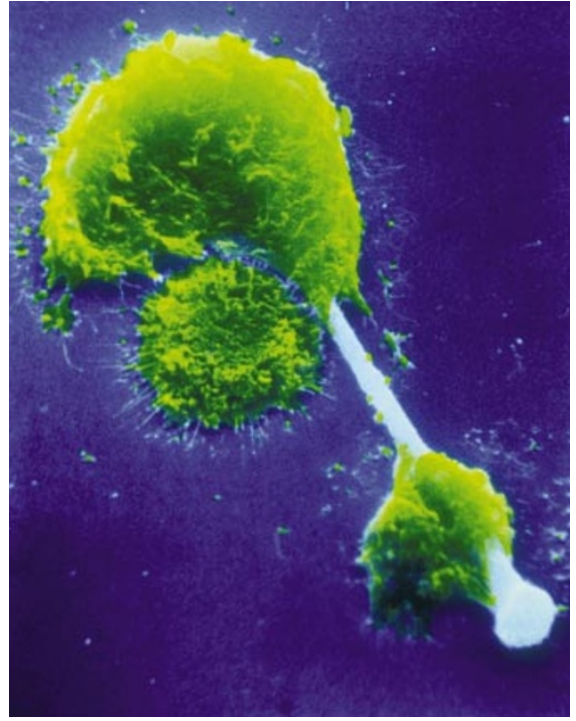

Gagged: data deprivation could halt studies on the health effects of asbestos fibres, seen here being attacked by cells of the immune system.

unlawfully in passing on confidential records without consent," he says.

New provisions passed earlier this month offer a solution, suggests the GMC's spokesman. A committee made up of patient groups and health professionals will discuss specific projects and advise the Secretary of State for Health, who has the power to waive the need for informed consent. But epidemiologists are unconvinced. "It remains unclear if the group can review hundreds of studies for approval without causing further delay or even the collapse of projects," says Coleman.

Peto wants the government to issue a broad exemption for epidemiological research. "No harm was ever done in the past and the new law wasn't even aimed at medical research," he says.

Epidemiologists elsewhere are watching the situation. The UK law was designed to implement the 1995 directive on data protection from the European Union, and other member states have introduced or are preparing similar legislation. Concerns about the impact of data protection laws on epidemiology are also rising in Japan, South Africa and Canada. 